\title{
A NOTE FROM THE EDITOR
}

Almost since the beginning of criminal justice education in institutions of higher education, there have been charges that instruction has been too technocratic--concerned with "nuts and bolts" and "standard operating procedures" of criminal justice agencies. In the last decade, major studies have assailed a lack of consideration of the philosophic and theoretical underpinnings and issues concerning crime and justice. This real or perceived failure led some faculty members in more established disciplines to look with suspicion (and sometimes disdain) at criminal justice education. It also stood in the way of criminal justice faculty being afforded the same respect (and often the same salaries and rank and promotion opportunities) as other faculty.

Much of this has changed in the past few years--thanks to changes emanating from recommendations of national commissions and of studies accomplished by the major academic/ professional associations in this young field of study. The Southern Association of Criminal Justice Educators can be proud that it was one of the earliest groups to call for academic parity for criminal justice education, while, at the same time, establishing standards for classroom and campus activities that would make criminal justice education worthy of such parity.

The article in this issue by Melissa Hickman, while damning in its own way of criminal justice education, nevertheless represents a step forward in the evolution of the discipline. That is, Ms. Hickman, winner of the SACJE Graduate Student Award last year, challenges the emphas is of the ideology and theory (as well as the technographic emphasis) of criminal justice education. Ms. Hickman cites the "moral panic" theory concerning creation of an inordinate fear of crime, far out of proportion to reported crime rates. She indicts the emphasis on "crime control" and solying the problems of police, courts and corrections through the "justice model," with its emphasis on tougher enforcement policies and imprisonment, because, she holds, this emphas is ignores ideologies which may better explain crime and justice in America, She warns criminal justice students to be wary of education that assumes a "concensus" viewpoint on American values and thus supports the status quo--protection of the property and lifestyle of the ruling upper classes. 
She holds--compellingly--that there is at least as much evidence that no concensus exists on American values, and that ideas really "compete," but because of their upperclass orientation, lawmakers, law enforcers, law adjudicators and communicators (i.e., media) choose a perspective that suits the interests of their classes.

One might argue that this idea is only a thinly-veiled call for more emphasis on Marxist theory in the classroom. Certainly the need to examine Marxist ideology is a part of the call, but beyond that, Ms. Hickman calls for consideration of a much broader concept-- that the definition of crime is in large part a product of social class, not a concensus of values of the American people. While this ideology is gained in a "Sociology of Crime" or "Criminology" course at some schools, it is seldom explored in other criminal justice courses, such as those examining issues, crime prevention, planning, policy, administration or problem-solving in criminal justice. Thus, as Ms. Hickman points out, there is a "critical" gap in the criminal justice student's education.

Hopefully more articles will follow which challenge the ideology and theory being taught in the criminal justice classroom. It's a step forward to argue over these issues.

Elsewhere in this issue, Sukchotrat and Lindquist examine the important question of whether police officers welcome or resent the hiring of civilian employees, while Montgomery and Hughes examine the special problems of dealing with the mentally retarded in the criminal justice system. Fishman calls on the Supreme Court to clearly speak to the moral issues surrounding 1 ife-and-death decisions such as capital punishment, and Campbe11, the 1981 SACJE Undergraduate Award winner, examines the search and seizure issue through an analysis of Payton v. New York. Finally, Lab, DeZee and Doerner examine the records of the last three ACJS annual meetings to determine the institutional and individual characteristics of program participants.

Add book reviews and it is an exciting issue that you'll want on the shelf of your library as well as on your own bookshelf. Accompanying this issue is an order form for the Southern Journal. Won't you forward it to your school library so that this valuable material will be available to your students and others interested in crime and justice studies?

Gene Stephens 